\title{
Kurkumin Menurunkan Ekspresi Tumor Necrosis Factor (TNF)- $\alpha$ Kompleks Oosit- Kumulus Sapi pada Kultur dengan Zalir Peritoneum Penderita Infertil Terkait Endometriosis
}

\author{
MY Ardianta W', Hendy Hendarto', Widjiati' \\ 'Departemen Obstetri dan Ginekologi, Fakultas Kedokteran, Universitas Airlangga, RSUD dr. Sutomo, Surabaya \\ ${ }^{2}$ Departemen Embriologi, Fakultas Kedokteran Hewan, Universitas Airlangga, Surabaya
}

\section{ABSTRAK}

Tujuan: Mempelajari pengaruh pemberian kurkumin terhadap ekspresi tumor necrosis factor (TNF)- $\alpha$ kompleks oosit-kumulus (KOK) sapi pada kultur zalir peritoneum penderita infertil dengan endometriosis ringan dan berat.

Bahan dan Metode: Penelitian ini merupakan penelitian eksperimental murni yang dilaksanakan di Laboratorium Embriologi Fakultas Kedokteran Hewan Universitas Airlangga antara April sampai Agustus 2014. Zalir peritoneum diambil dari penderita infertil dengan endometriosis ringan, endometriosis berat, dan non-endometriosis yang menjalani laparoskopi diagnosis di Klinik Fertilitas Graha Amerta RSUD dr. Sutomo Surabaya, RS Bersalin Putri Surabaya, RSIA Kendangsari Surabaya, RS Universitas Airlangga Surabaya. Masing-masing zalir peritoneum endometriosis ringan dan berat dibagi lagi menjadi zalir peritoneum endometriosis dengan kurkumin dan tanpa kurkumin. Zalir peritoneum non endometriosis dikelompokkan menjadi zalir peritoneum penderita non endometriosis tanpa dan dengan kurkumin. KOK sapi diambil secara consecutive sampling dari aspirasi folikel antral diameter 3-8 $\mathrm{mm}$ dari ovarium sapi yang berasal dari Rumah Potong Hewan Surabaya kemudian secara acak dengan randomisasi sederhana dikultur dalam tujuh kelompok. Kelompok 1 ditempatkan dalam tissue culture medium 199 (TCM-199) saja. Kelompok 2, 3 dan 4 TCM199 ditambah masing-masing 3\% zalir peritoneum penderita infertil dengan endometriosis ringan, berat dan non-endometriosis. Kelompok 5, 6, dan 7 media TCM-199 ditambah masing-masing $3 \%$ zalir peritoneum penderita infertil dengan endometriosis ringan, berat dan non-endometriosis dan dengan kurkumin 20 $\mu \mathrm{g} / \mathrm{ml}$.

Hasil: Uji Kruskal Wallis menunjukkan perbedaan yang bermakna ekspresi TNF- $\alpha$ pada ketujuh kelompok $(\mathrm{p}<0,0001)$. Uji Mann-Whitney juga menunjukkan bahwa ekspresi TNF- $\alpha$ KOK sapi pada kultur kelompok endometriosis ringan dengan kurkumin $(\mathrm{ER}+\mathrm{C})$ lebih rendah secara bermakna dibandingkan kelompok endometriosis ringan tanpa kurkumin (ER). Ekspresi TNF- $\alpha$ KOK sapi pada kultur kelompok endometriosis berat dengan kurkumin $(\mathrm{EB}+\mathrm{C})$ lebih rendah secara bermakna dibandingkan kelompok endometriosis berat tanpa kurkumin (EB). Uji Mann-Whitney menunjukkan ekspresi TNF- $\alpha$ KOK sapi pada kultur kelompok ER lebih tinggi secara bermakna dibandingkan kontrol ataupun kelompok non endometriosis (NE). Ekspresi TNF- $\alpha$ KOK sapi pada kultur kelompok EB lebih tinggi secara bermakna dibandingkan kontrol ataupun kelompok NE. Ekspresi TNF- $\alpha$ KOK sapi pada kultur kelompok EB tidak didapatkan perbedaan yang bermakna dibandingkan dengan kelompok ER.

Simpulan: Pemberian kurkumin dapat dipertimbangkan untuk digunakan sebagai terapi tambahan pada penderita infertil terkait endometriosis.

Kata kunci: Kurkumin, endometriosis, zalir peritoneum, infertilitas, TNF- $\alpha$, kompleks oosit-kumulus, kultur.

\begin{abstract}
Objective: To study the effect of curcumin on the expression of tumor necrosis factor (TNF)- $\alpha$ of cow's oocyte-cumulus complex (OCC) in cultured peritoneal fluid of infertile patients with mild and severe endometriosis.

Materials and Methods: This study was a pure experimental study conducted at the Laboratory of Embryology, Faculty of Veterinary Medicine, Airlangga University, between April and August 2014. Peritoneal fluid was taken from infertile patients with mild endometriosis, severe endometriosis and nonendometriosis who underwent laparoscopic diagnosis in Fertility Clinic, Graha Amerta, Dr. Sutomo Hospital, Surabaya, Putri Maternity Hospital Surabaya, RSIA Surabaya Kendangsari, and Airlangga University Hospital. Each mild and severe endometrial peritoneal fluid was subdivided into endometrial peritoneal fluid with and without curcumin. Non endometrial peritoneal fluid was grouped into non endometrial peritoneal fluid without and with curcumin. Cow's OCC was taken by consecutive sampling of from antral follicle aspiration in 3-8 $\mathrm{mm}$ diameter from cow ovaries originating from Slaughterhouse Surabaya then randomly with a simple randomized cultured in seven groups. Group 1 was placed in a tissue culture medium 199 (TCM-199) only. Groups 2, 3 and 4 TCM-199 added respectively with 3\% peritoneal fluid of infertile patients with mild, severe endometriosis and nonendometriosis. In groups 5, 6, and 7 TCM-199 medium was added respectively with $3 \%$ peritoneal fluid of infertile patients with mild, severe endometriosis and non-endometriosis and with curcumin $20 \mathrm{ug} / \mathrm{ml}$.

Results: Kruskal Wallis test showed no significant difference in the expression of TNF- $\alpha$ in the seven groups ( $\mathrm{p}<0.0001)$. While the Mann-Whitney test also showed that the expression of TNF- $\alpha$ in cow's OCC in cultured group of mild endometriosis with curcumin $(\mathrm{ER}+\mathrm{C})$ was significantly lower than that in the group of mild endometriosis without curcumin (ER). TNF- $\alpha$ expression of cow's OCC on culture severe endometriosis group with curcumin $(\mathrm{EB}+\mathrm{C})$ was significantly lower than the group without curcumin severe endometriosis (EB). Mann-Whitney test showed the expression of TNF- $\alpha$ of cow's OCC in ER group culture was significantly higher than that in control or in non endometriosis (NE) group. TNF- $\alpha$ expression in cow's OCC in EB group culture was significantly higher than that in control group or NE group. TNF- $\alpha$ expression of cow's OCC in EB group culture had no significant difference compared to that in ER group.
\end{abstract}

Conclusion: Curcumin can be considered for use as adjunctive therapy in patients with endometriosis-related infertility.

Keywords: curcumin, endometriosis, peritoneal fluid, infertility, TNF- $\alpha$, oocyte-cumulus complexes, culture

Correspondence: MY Ardianta W, Departemen Obstetri dan Ginekologi, Fakultas Kedokteran, Universitas Airlangga, RSUD dr. Sutomo, Jalan Mayjen Prof dr Mustopo 6-8, Surabaya 60286. Telp. 62-31-5501474. Email: drwidyanugraha@gmail.com 


\section{PENDAHULUAN}

Endometriosis didefinisikan sebagai adanya jaringan meyerupai endometrium (endometrial-like tissue) di luar kavum uteri, yang menginduksi reaksi inflamasi kronis. ${ }^{1}$ Secara umum prevalensi endometriosis pada populasi wanita diperkirakan sekitar 6-10\%. ${ }^{2}$ Salah satu keluhan pasien dengan endometriosis adalah infertil. Di klinik fertilitas Graha Amerta RSU dr Sutomo pada wanita infertil yang dilakukan laparoskopi diagnostik didapatkan endometriosis pelvis : $23,8 \%$ (1987), $37,2 \%$ (1993) dan 50\% (2002). ${ }^{3}$

Infertilitas didefinisikan sebagai ketidakmampuan untuk terjadinya kehamilan setelah satu tahun berhubungan seksual tanpa proteksi. ${ }^{4}$ Pada endometriosis, sebuah konsep umum yang penting adalah bahwa pada endometriosis terjadi proses inflamasi lokal pada pelvis dengan perubahan fungsi sel-sel terkait sistem imun di lingkungan peritoneum. ${ }^{5}$ Beberapa pendekatan dari patomekanisme infertilitas pada endometriosis, berdasarkan dampaknya terhadap sejumlah kondisi patologis, adalah: adanya perlengketan pelvis dan endometrioma, folikulogenesis yang abnormal dan gangguan fungsi oosit, perubahan fungsi sperma, kualitas embrio berkurang, dan gangguan reseptivitas endometrium. ${ }^{6}$

Pendekatan diatas didukung oleh penelitian Hendarto dkk (2010) yang membuktikan terjadinya penurunan GDF-9 (faktor pertumbuhan yang disekresi oosit) pada zalir folikel penderita infertil dengan endometriosis. Mekanisme penurunan ini diduga akibat pengaruh sitokin yaitu TNF- $\alpha$ yang memicu apoptosis sel granulosa sehingga terjadi penurunan nutrisi yang diberikan terhadap oosit dan berakibat pada penurunan GDF-9. ${ }^{7}$ Demikian pula, penelitian yang kemudian dilakukan oleh Myrnawati dkk (2012) mendapatkan ekspresi GDF-9 KOK sapi pada kultur zalir peritoneum penderita infertil dengan endometriosis lebih rendah secara bermakna jika dibandingkan pada kultur zalir peritoneum penderita infertil non-endometriosis maupun kontrol. $^{8}$

Pemberian kurkumin sebagai terapi endometriosis saat ini masih kontroversi. Hal ini mungkin karena belum banyak penelitian dan publikasi tentang pemberian kurkumin sebagai terapi endometriosis khususnya dalam masalah infertilitas terkait endometriosis. Dalam artikelnya, Swarnakar dan Paul (2009) menyebutkan bahwa manfaat kurkumin pada berbagai penyakit di antaranya adalah sebagai antiinflamasi dan penghambatan pada NF-kB. Berdasarkan hal tersebut, kurkumin diduga memberi manfaat sebagai terapi pada endometriosis. ${ }^{9}$
Penelitian ini mencoba untuk mempelajari pengaruh kurkumin terhadap ekspresi TNF- $\alpha$ sebagai sitokin inflamasi yang dominan pada zalir peritoneum dan sel granulosa. Mengingat kurkumin belum pernah digunakan pada manusia untuk pengobatan endometriosis dengan infertilitas dan penelitian pada manusia untuk mengetahui efek kurkumin terkendala etika, maka pada penelitian ini digunakan kompleks oosit kumulus sapi.

\section{BAHAN DAN METODE}

Penelitian ini merupakan penelitian eksperimental murni yang dilakukan di laboratorium embriologi Fakultas Kedokteran Hewan UNAIR Surabaya. Zalir peritoneum diambil dari penderita infertil dengan endometriosis ringan (revised American Fertility Society, rAFS I-II), endometriosis berat (revised American Fertility Society, r-AFS III-IV) dan non endometriosis yang menjalani laparoskopi diagnosis di Klinik Fertilitas Graha Amerta RSUD dr. Sutomo Surabaya, RS Bersalin Putri Surabaya, RSIA Kendang-sari Surabaya, RS Universitas Airlangga Surabaya. Masing-masing zalir peritoneum endometrio-sis ringan dan berat yang ditemukan saat laparoskopi kemudian dibagi lagi menjadi zalir peritoneum endo-metriosis dengan kurkumin dan tanpa kurkumin. Zalir peritoneum non endometriosis yang diambil kemudian juga dikelompokkan menjadi 2 kelompok yaitu zalir peritoneum penderita non-endometriosis tanpa dan dengan kurkumin.

Kriteria inklusi untuk penderita infertil dengan endometriosis adalah pasien infertil dengan endometrio-sis ringan, endometriosis berat atau non endometriosis yang menjalani diagnosis dengan laparoskopi, umur 20-40 tahun, siklus haid teratur 28 hari \pm 3 hari, pemeriksa-an laboratorium $(\mathrm{Hb}$, lekosit, trombosit, hematokrit, gula darah puasa/2 jam post prandial, fungsi liver, fungsi ginjal) dalam batas normal, bersedia ikut peneliti-an dengan menandatangani surat perjanjian. Sedangkan kriteria eksklusi adalah saat laparoskopi didapatkan penyakit radang panggul (temperatur rektal $>38^{\circ} \mathrm{C}$, keputihan, nyeri panggul), sindroma ovarium polikistik, tumor ovarium selain endometrioma, asites, pernah mendapatkan pengobatan hormon untuk endo-metriosis dalam waktu 6 bulan terakhir.

KOK sapi diambil secara consecutive sampling dari aspirasi folikel antral diameter 3-8 $\mathrm{mm}$ dari ovarium sapi yang berasal dari Rumah Potong Hewan Surabaya. Kriteria inklusi untuk folikel sapi adalah folikel antral dengan diameter permukaan 3-8 $\mathrm{mm}$ yang diperoleh dari ovarium sapi yang berasal dari limbah Rumah Potong Hewan Surabaya. Kriteria eksklusi untuk folikel sapi adalah ovarium dengan kualitas jelek (folikel tidak 
baik/kempis). KOK yang didapat kemudian secara acak dengan randomisasi sederhana dikultur dalam tujuh kelompok yaitu yang pertama ditempatkan dalam tissue culture medium 199 (TCM-199) saja, pada kelompok kedua, ketiga dan keempat media TCM-199 masingmasing ditambah dengan 3\% zalir peritoneum penderita infertil dengan endometriosis ringan, endometriosis berat dan non endometriosis, pada kelompok kelima, keenam dan ketujuh media TCM-199 masing-masing ditambah dengan $3 \%$ zalir peritoneum penderita infertil dengan endometriosis ringan, endometriosis berat dan non endometriosis yang masing-masing ditambah dengan kurkumin 20 ug/ml.

Setelah diinkubasi pada suhu $38^{\circ} \mathrm{C}$ dalam $\mathrm{CO} 25 \%$ selama 20 jam, KOK sapi difiksasi dalam gelas obyek, diwarnai secara imuno-sitokimia kemudian dilakukan pengukuran ekspresi TNF- $\alpha$. Kultur KOK sapi dalam zalir peritoneum wanita endometriosis ini menggunakan media kultur jaringan Tissue Culture Medium (TCM)199 yang merupakan media standar untuk maturasi in vitro pada sapi. Kelayakan etik penelitian kami dapatkan dari komite etik Fakultas Kedokteran Hewan Universitas Airlangga, Surabaya dan RSUD dr. Sutomo, Surabaya.

Besar sampel menggunakan rumus Lemeshow dan setelah dikoreksi dengan faktor koreksi dari penelitian pendahuluan sebelumnya didapatkan besar sampel pada masing-masing kelompok adalah 7. Semua data yang terkumpul dianalisis dengan uji beda Kruskal-Wallis yang dilanjutkan uji komparasi ganda Mann-Whitney. Tingkat kemaknaan yang digunakan 95\% atau $\mathrm{p}<0,05$.

\section{HASIL DAN PEMBAHASAN}

Pada penelitian ini, sampel zalir peritoneum diperoleh secara konsekutif dari 21 penderita yang dilakukan laparoskopi untuk kasus infertilitas, yang memenuhi kriteria inklusi dan eksklusi, di klinik fertilitas Graha Amerta Surabaya, RSIA Kendangsari Surabaya, RSIA Putri Surabaya, RS Universitas Airlangga Surabaya dengan rincian 7 penderita infertil dengan endometriosis ringan (r-AFS stadium I-II), 7 penderita infertil dengan endometriosis berat (r-AFS stadium III-IV) dan 7 penderita infertil non endometriosis.

Kompleks oosit-kumulus yang telah difiksasi pada gelas obyek kemudian dilakukan pewarnaan secara imunositokimia dan diperiksa di bawah mikroskop. Ekspresi TNF- $\alpha$ divisualisasikan dengan warna coklat bila preparat immunositokimia diamati di bawah mikroskop. Warna coklat disebabkan terikatnya antigen dan antibodi (Gambar 1).

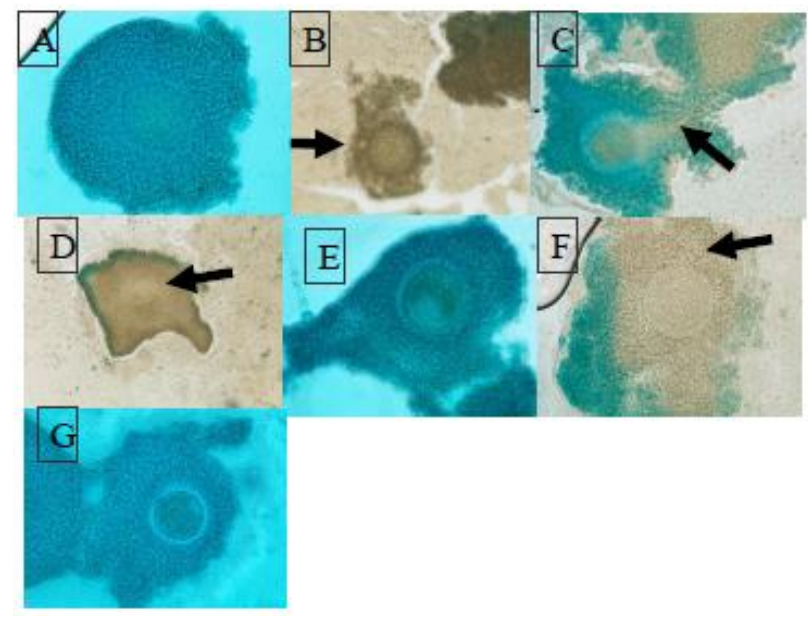

Gambar 1. Gambar hasil pemeriksaan imunositokimia pada kelima medium kultur

Gambar A menunjukkan ekspresi TNF $\alpha$ pada KOK pada kelompok kontrol dengan skor 0. Pada slide ini tidak ditemukan sel immunoreaktif sama sekali (Pewarnaan IHC: 400x; Olympus BX-50. Pentax optio 230 Camera Digital 2.0 megapixel). Gambar B menunjukkan ekspresi TNF $\alpha$ pada KOK pada kelompok Endometriosis Berat dengan skor 4. Jumlah Sel immunoreaktif (panah) lebih dari $80 \%$ dari seluruh lapangan pandang (Pewarnaan IHC: 400x; Olympus BX-50. Pentax optio 230 Camera Digital 2.0 megapixel). Gambar C menunjukkan ekspresi TNF $\alpha$ pada KOK pada kelompok Endometriosis Berat +Curcumin dengan skor 2. Jumlah Sel immunoreaktif (panah) antara $10 \%$ hingga $50 \%$ dari seluruh lapangan pandang (pewarnaan IHC; 400x; Olympus BX-50. Pentax optio 230 Camera Digital 2.0 megapixel). Gambar D menunjukkan ekspresi TNF $\alpha$ pada KOK pada kelompok Endometriosis Ringan dengan skor 3. Jumlah Sel immunoreaktif (panah) lebih dari $80 \%$ dari seluruh lapangan pandang (Pewarnaan IHC: 400x; Olympus BX-50. Pentax optio 230 Camera Digital 2.0 megapixel). Gambar E menunjukkan ekspresi TNF $\alpha$ pada KOK pada kelompok Endometriosis Ringan +Curcumin dengan skor 1 . Jumlah Sel immunoreaktif (panah) antara 10\% hingga 50\% dari seluruh lapangan pandang (pewarnaan IHC; 400x; Olympus BX-50. Pentax optio 230 Camera Digital 2.0 megapixel). Gambar F menunjukkan ekspresi TNF $\alpha$ pada KOK pada kelompok Non Endometriosis dengan skor 3. Jumlah Sel immunoreaktif (panah) lebih dari $80 \%$ dari seluruh lapangan pandang (Pewarnaan IHC: 400x; Olympus BX-50. Pentax optio 230 Camera Digital 2.0 megapixel). Gambar G menunjukkan ekspresi TNF $\alpha$ pada KOK pada kelompok Endometriosis Ringan +Curcumin dengan skor 1. Jumlah Sel immunoreaktif (panah) antara 10\% hingga 50\% dari seluruh lapangan pandang (pewarnaan IHC; 400x; Olympus BX-50. Pentax optio 230 Camera Digital 2.0 megapixel).

Pada kelompok kontrol diperoleh hasil ekspresi minimum sebesar 0,00 dan maksimum 0,00 dengan median 0,00 dan rerata 0,00 sehingga dapat dikatakan bahwa pada KOK kelompok kontrol tidak didapatkan ekspresi TNF- $\alpha$ sama sekali. Ini merupakan ekspresi 
TNF- $\alpha$ yang paling rendah dibandingkan dengan tujuh kelompok lainnya. Pada kelompok EB diperoleh hasil ekspresi minimum sebesar 8,00 dan maksimum 12,00 dengan median 9,00 dan rerata 10,142. Pada kelompok $\mathrm{EB}+\mathrm{C}$ diperoleh ekspresi minimum sebesar 2,00 dan maksimum 6,00 dengan median 4,00 dan rerata 3,8571. Pada kelompok ER diperoleh hasil ekspresi minimum sebesar 6,00 dan maksimum 12,00 dengan median 12,00 dan rerata 9,4286. Pada kelompok ER+C diperoleh hasil ekspresi minimum sebesar 0,00 dan maksimum 2,00 dengan median 1,00 dan rerata 1,00. Pada kelompok NE diperoleh hasil ekspresi minimum sebesar 6,00 dan maksimum 9,00 dengan median 4,00 dan rerata 5,5714. Pada kelompok NE+C diperoleh hasil ekspresi minimum sebesar 0,00 dan maksimum 2,00 dengan median 1,00 dan rerata 0,7143 . Uji statistik mengguna-kan Kruskal Wallis menunjukkan adanya perbedaan bermakna ekspresi TNF- $\alpha$ antara ketujuh kelompok kultur (Tabel 1).

Sedangkan uji Mann-Whitney juga menunjukkan bahwa ekspresi TNF- $\alpha$ KOK sapi pada kultur kelompok ER+C lebih rendah secara bermakna dibandingkan kelompok ER ( $\mathrm{p}=0,001)$, demikian pula ekspresi TNF- $\alpha$ KOK sapi pada kultur kelompok $\mathrm{EB}+\mathrm{C}$ lebih rendah secara bermakna dibandingkan kelompok $\mathrm{EB}(\mathrm{p}=0,002)$.

Uji Mann-Whitney menunjukkan ekspresi TNF- $\alpha$ KOK sapi pada kultur kelompok ER lebih tinggi secara bermakna dibandingkan kelompok kontrol $(\mathrm{p}=0,001)$ ataupun kelompok $\mathrm{NE} \quad(\mathrm{p}=0,021)$, demikian pula ekspresi TNF- $\alpha$ KOK sapi pada kultur kelompok EB lebih tinggi secara bermakna dibandingkan kontrol $(\mathrm{p}=0,001)$ ataupun kelompok NE $(\mathrm{p}=0,004)$. Sedangkan ekspresi TNF- $\alpha$ KOK sapi pada kultur kelompok EB tidak didapatkan perbedaan yang bermakna dibandingkan dengan kelompok ER ( $\mathrm{p}=0,730)$.

Pada penelitian kami ini, didapatkan Ekspresi TNF- $\alpha$ KOK sapi pada kultur kelompok $\mathrm{ER}+\mathrm{C}$ lebih rendah secara bermakna dibandingkan pada kelompok ER.
Demikian pula didapatkan ekspresi TNF- $\alpha$ KOK sapi pada kultur kelompok $\mathrm{EB}+\mathrm{C}$ lebih rendah secara bermakna dibandingkan pada kelompok EB.

Penelitian ini mempelajari pengaruh kurkumin terhadap ekspresi Tumor Necrosis Factor (TNF)- $\alpha$ kompleks oosit-kumulus sapi pada kultur zalir peritoneum penderita infertil dengan endometriosis ringan dan berat in vitro. TNF- $\alpha$ merupakan mediator utama dalam proses inflamasi dan kadar TNF- $\alpha$ dalam zalir perito-neum wanita dengan endometriosis telah terbukti terjadi peningkatan secara signifikan. ${ }^{10,11}$ Infertilitas adalah salah satu keluhan penderita dengan endometriosis yang tatalaksananya hingga kini masih belum juga memberikan hasil yang memuaskan. Sebuah konsep umum yang penting adalah bahwa pada endometriosis terjadi proses inflamasi lokal pada pelvis dengan perubahan fungsi sel-sel terkait sistem imun di lingkungan peritoneum. ${ }^{5}$

Zalir peritoneum telah menjadi fokus penelitian pada endometriosis karena dianggap berpotensi memberikan informasi tentang endometriosis. Zalir peritoneum, mengingat kedekatan letaknya dengan lesi endometriosis, merupakan lingkungan tempat terjadinya tidak hanya inflamasi lokal namun juga sejumlah peristiwa reproduksi awal seperti ovulasi, pengambilan ovum, dan interaksi sperma-oosit. ${ }^{12}$ Keterkaitan zalir peritoneum untuk lesi endometriosis diantaranya didapatkannya mediator sistem kekebalan terkait dengan inflamasi lokal. ${ }^{13}$

TNF- $\alpha$ di dalam zalir peritoneum penderita infertil dengan endometriosis secara signifikan lebih tinggi dibandingkan dengan non endometriosis. ${ }^{14}$ Tingginya tingkat TNF- $\alpha$ yang terdeteksi menunjukkan adanya produksi lokal dari makrofag peritoneal yang diaktifkan. Peningkatan produksi TNF- $\alpha$ yang diduga berasal dari proses radang pada lingkungan pelvis ini kemudian secara langsung berdifusi masuk ke dalam folikel. ${ }^{11,15,16,17}$

Tabel 1. Ekspresi TNF- $\alpha$ KOK yang dikultur dalam 7 kelompok medium dan uji perbandingan pada kelompok penelitian

\begin{tabular}{|c|c|c|c|c|c|c|c|c|c|c|c|}
\hline \multirow[t]{2}{*}{ Kelompok } & \multirow[t]{2}{*}{$\mathrm{N}$} & \multirow[t]{2}{*}{ Mean } & \multirow[t]{2}{*}{ Median } & \multirow[t]{2}{*}{ Minimum } & \multirow[t]{2}{*}{ Maksimum } & \multirow{2}{*}{$\begin{array}{c}\text { Uji } \\
\text { Kruskal- } \\
\text { Wallis } \\
\text { Harga } p \\
\end{array}$} & \multicolumn{5}{|c|}{ Uji Mann-Whitney } \\
\hline & & & & & & & $\mathrm{EB}: \mathrm{EB}+\mathrm{C}$ & ER:ER+C & EB:ER & EB:NE & ER:NE \\
\hline EB & 7 & 10,1429 & 9,00 & 8,00 & 12,00 & \multirow{8}{*}{$<0,0001$} & \multirow{8}{*}{0,002} & \multirow{8}{*}{0,001} & \multirow{8}{*}{0,730} & \multirow{8}{*}{0,004} & \multirow{8}{*}{0,021} \\
\hline $\mathrm{EB}+\mathrm{C}$ & 7 & 3,8571 & 4,00 & 2,00 & 6,00 & & & & & & \\
\hline ER & 7 & 9,4286 & 12,00 & 6,00 & 12,00 & & & & & & \\
\hline $\mathrm{ER}+\mathrm{C}$ & 7 & 1,00 & 1,00 & 0,00 & 2,00 & & & & & & \\
\hline NE & 7 & 5,5714 & 6,00 & 4,00 & 9,00 & & & & & & \\
\hline $\mathrm{NE}+\mathrm{C}$ & 7 & 0,7143 & 1,00 & 0,00 & 2,00 & & & & & & \\
\hline K & 7 & 0,00 & 0,00 & 0,00 & 0,00 & & & & & & \\
\hline Total & 49 & 4,8857 & 4,00 & 0,00 & 12,00 & & & & & & \\
\hline
\end{tabular}



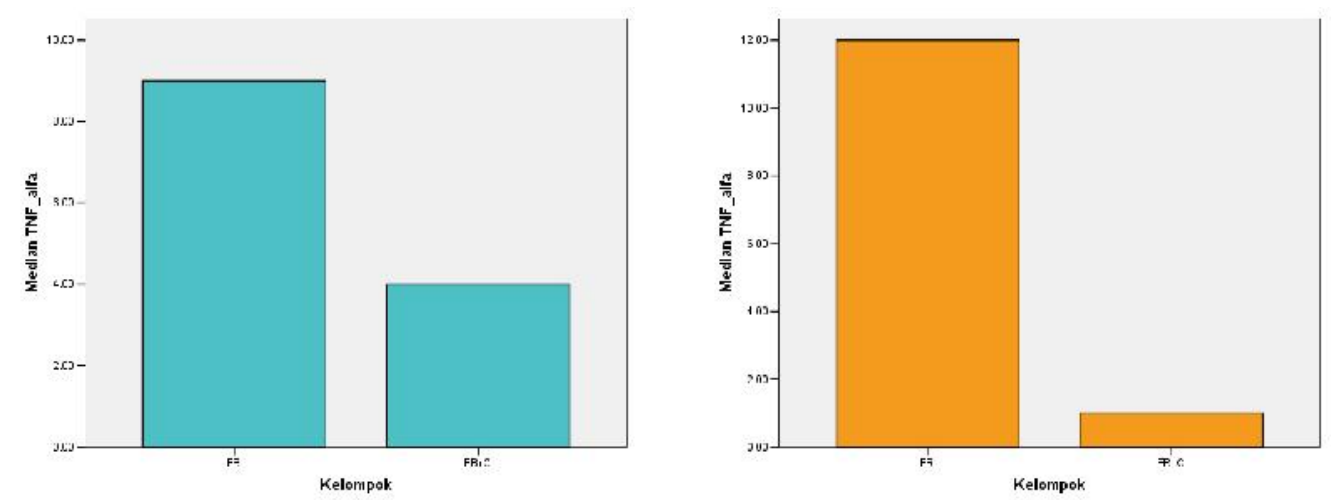

Gambar 2. Diagram median ekspresi TNF- $\alpha$ KOK pada kelompok kultur endometriosis tanpa kurkumin dan endometrios dengan Kurkumin.

TNF- $\alpha$ juga menghambat perkembangan oosit/folikel. Efek penghambatan ini disebabkan oleh efek yang merangsang apoptosis. Pendapat diatas didukung oleh penelitian Hendarto dkk (2010) yang membuktikan terjadinya penurunan GDF-9 (faktor pertumbuhan yang disekresi oosit) pada zalir folikel penderita infertil dengan endometriosis. Mekanisme penurunan ini diduga akibat pengaruh sitokin yaitu TNF- $\alpha$ yang memicu apoptosis sel granulosa sehingga terjadi penurunan nutrisi yang diberikan terhadap oosit dan berakibat pada penurunan GDF-9. ${ }^{7}$

TNF- $\alpha$ memediasi berbagai respons biologis termasuk peradangan, infeksi, injury dan apoptosis sel. Efek dari TNF- $\alpha$ diinisiasi oleh ikatan sitokin terhadap reseptor, yang menyebabkan aktivasi dari faktor utama transkripsi diantaranya nuclear factor kappa $\mathrm{B}(\mathrm{NF}-\kappa \mathrm{B})$. Aktivasi tersebut kemudian menginduksi gen yang terlibat dalam respon inflamasi. Selain itu TNF- $\alpha$ juga dapat memicu apoptosis melalui ikatannya dengan death receptor. $^{18}$

Ikatan TNF dengan reseptor kematian dengan efek apoptosis melalui aktivasi caspase 8 . Kematian sel yang diinisiasi reseptor ini dimulai dengan perekrutan adapter protein, seperti FADD (Fas associated death domain), melalui DD (death domain), yang kemudian berikatan dengan efektor kematian yang mengandung caspase-8 atau-10. Pembentukan DISC ini (death inducing signaling complex) menghasilkan aktivasi caspase-8/10, yang kemudian mengaktifkan caspase-3 sebagai eksekutor. ${ }^{19,20,21,22}$

Sel-sel yang diaktifkan oleh sitokin mungkin memproduksi dan mensekresikan sitokin yang sama sebagai sinyal parakrin atau untuk meningkatkan dan menstabilkan sinyal dalam sel yang mensekresi melalui regulasi autokrin. Mekanisme autokrin atau parakrin produksi TNF- $\alpha$ melibatkan beberapa protein, diantara- nya NF- $\kappa \mathrm{B}$, penghambat $\mathrm{I} \kappa \mathrm{B} \alpha$ dan $\mathrm{A} 20$, penghantar sinyal kinase IKK dan IKKK, sitokin TNF- $\alpha$ dan reseptornya TNFR1. ${ }^{23}$ Gonzalez-Navarrete dkk (2007) melaporkan dalam penelitiannya bahwa TNF- $\alpha$ mengaktifkan jalur NF-кB di sel granulosa manusia. Zolti dkk (1990) melaporkan bahwa sel-sel granulosa adalah sumber dan organ target untuk TNF- $\alpha$. Tumor necrosis factor (TNF)- $\alpha$, selain diproduksi oleh makrofag aktif juga diproduksi oleh sel granulosa dari tikus dan sapi. Dalam hal ini TNF- $\alpha$ juga dapat bersifat autokrin (dihasilkan oleh organ target, granulosa folikel). ${ }^{24,25}$ Dengan semakin meningkatnya produksi TNF- $\alpha$ melalui mekanisme autokrin, dapat memperberat efek dari TNF$\alpha$ tersebut.

Pemberian kurkumin sebagai terapi endometriosis didasari bahwa manfaat kurkumin pada berbagai penyakit diantaranya adalah sebagai antiinflamasi dan penghambatan pada NF-кB. ${ }^{9}$ Efek antiinflamasi kurkumin dimediasi melalui penekanan terhadap faktor transkripsi NF-kB. Kurkumin menghambat aktivasi NF$\kappa \mathrm{B}$ dengan mencegah fosforilasi dan degradasi $\mathrm{I} \kappa \mathrm{B} \alpha$. Kurkumin tidak secara langsung mengganggu aktifitas NIK atau IKK. Kurkumin memblok degradasi IкB yang diinduksi baik oleh IL- $1 \beta$ atau TNF- $\alpha$, melalui messenger yang digunakan baik oleh jalur IL-1 $\beta$ atau TNF- $\alpha$. Efek dari kurkumin tersebut mungkin disebabkan oleh gangguan transmisi sinyal protein adapter seperti RIP, TRAF-2, atau TRAF-6, yang memicu aktivasi dari MEKK, NIK, atau IKK. Kemungkinan lainnya adalah bahwa kurkumin menghambat aktivitas dari messenger yang diinduksi baik oleh IL-1 $\beta$ atau TNF- $\alpha$ yang mampu mengaktifkan NIK dan/atau IKK. Jobin dkk (1999) menyimpulkan bahwa kurkumin menghambat aktivasi NF- $\mathrm{B}$ yang dimediasi sitokin (cytokinemediated NF- $\mathrm{kB}$ ) dengan memblokir sinyal yang memicu aktivasi IKK. ${ }^{26,27}$ 
Selain menghambat ekspresi TNF- $\alpha$, pengaruh kurkumin terhadap TNF- $\alpha$ yaitu memblok sinyal TNF- $\alpha{ }^{26}$ Kurkumin dapat berikatan secara langsung dengan molekul-molekul pro-inflamasi. Salah satu dari berbagai molekul inflamasi yang diketahui berikatan secara langsung dengan kurkumin adalah tumor necrosis factor (TNF)- $\alpha$. Dalam sebuah penelitian yang dilakukan Wua dkk (2010), kurkumin didapatkan menempati receptor binding TNF- $\alpha{ }^{28}$

Dalam studi ini kami telah menyelidiki konsentrasi TNF- $\alpha$ baik pada kultur KOK sapi yang ditambah dengan zalir peritoneum penderita infertil endometriosis ringan, penderita infertil endometriosis berat, dan penderita infertil non-endometriosis. Tingkat TNF- $\alpha$ didapatkan tidak berbeda secara signifikan pada kelompok ER dibandingkan dengan kelompok EB, namun didapatkan perbedaan secara bermakna antara kelompok NE dengan kelompok ER atau kelompok EB.

Temuan kami sesuai dengan hasil penelitian sebelumnya yang dilakukan oleh Bedaiwy dkk (2002), namun berbeda dengan hasil yang didapatkan oleh Richter dkk (2005). Meskipun kadar TNF- $\alpha$ pada penelitian Richter dkk mencerminkan keparahan endometriosis, namun kami tidak melihat hubungan ini dalam penelitian kami. Jumlah pada kelompok penelitian yang terbatas, baik pada penelitian kami maupun pada penelitian Richter dkk mungkin menjadi penyebab temuan yang tidak kompatibel ini, namun hasil penelitian kami ini sesuai dengan hasil penelitian Bedaiwy dkk (2002) yang menggunakan jumlah sampel jauh lebih besar. Selain itu, dalam laporan sebelumnya para peneliti menyebutkan bahwa terjadi penurunan imunitas selular pada endometriosis, dimana hal ini mengasumsikan bahwa makrofag tidak mempunyai kapasitas yang cukup untuk bekerja membersihkan rongga pelvik dari debris regurgitasi, sehingga hal ini kami duga ikut bertanggung jawab terhadap pengurangan kapasitas produksi TNF- $\alpha$. Kemungkinan yang lain adalah seperti yang dijelaskan dalam publikasi oleh Olive dkk (1985) yang menyebutkan bahwa tingkat endometriosis umum-nya tidak terkait dengan jumlah makrofag. ${ }^{29,30}$

Penelitian ini mengajukan konsep bahwa oosit dalam kompleks oosit-kumulus yang diinkubasi dalam zalir peritoneum penderita infertil dengan endometriosis akan mengalami gangguan pertumbuhan dan maturasi akibat berkurangnya nutrisi oosit yang disebabkan oleh apoptosis sel granulosa yang dipicu oleh TNF- $\alpha$ yang terkandung di dalam zalir. Pemberian kurkumin (yang mempunyai aktifitas sebagai antiinflamasi dan menghambat NF- $\mathrm{kB}$ ) pada kultur zalir peritoneum wanita infertil dengan endometriosis diharapkan dapat menghambat aktivitas dan ekspresi TNF- $\alpha$ pada kompleks oosit-kumulus. Kompleks oosit-kumulus yang diguna- kan diambil dari folikel yang berasal dari sapi (bovine) dengan pertimbangan folikulogenesis sapi menyerupai manusia serta kemudahan tehnik untuk mendapatkan folikel antral yang mengandung kompleks oositkumulus.

Penelitian kami menunjukkan bahwa pemberian kurkumin pada endometriosis ringan maupun berat dapat menekan reaksi inflamasi yang terlihat pada rendahnya TNF- $\alpha$ pada kultur KOK yang ditambah dengan zalir peritoneum penderita infertil.

\section{SIMPULAN}

Pemberian kurkumin dapat dipertimbangkan untuk digunakan sebagai terapi tambahan pada penderita infertil terkait endometriosis.

\section{DAFTAR PUSTAKA}

1. Kennedy S, Bergqvist A, Chapron C, D'Hooghe T, Dunselman G, Greb R, Hummelshoj L, Prentice A and Saridogan E. on behalf of the ESHRE Special Interest Group for Endometriosis and Endometrium Guideline Development Group. ESHRE guideline for the diagnosis and treatment of endometriosis. Human Reproduction. 2005;20(10):2698-704.

2. Baldi A, Campioni $M$ and Signorile PG. Endometriosis: Pathogenesis, diagnosis, therapy and association with cancer (Review). Oncology Report. 2008;19:843-6.

3. Samsulhadi. Endometriosis: Dari biomolekuler sampai masalah klinis Endometriosis : from biomoleculer to clinical application). Majalah Obstetri dan Ginekologi. 2002;10:43-50.

4. ASRM. Infertility: An Overview, A Guide for Patients. American Society for Reproductive Medicine. 2012.

5. Harada $\mathrm{T}$, Iwabe $\mathrm{T}$ and Terakawa $\mathrm{N}$. Role of cytokines in endometriosis. Fertility and Sterility. 2001;76(1).

6. Hendarto H. Pathomechanism of infertility in endometriosis, in Endometriosis-basic Concept and Current Research Trends. Intech. 2012:343-53.

7. Hendarto H, Prabowo P, Moeloek FA and Soetjipto S. Growth differentiation factor-9 concentration in the follicular fluid of infertile women with endometriosis. Fertility and Sterility. 2010; 94(2):758-60.

8. Myrnawati M, Hendarto H, Widjiati dan Azinar LD. Ekspresi Growth Differentiation Factor-9 (GDF-9) kompleks oosit-kumulus sapi pada kultur zalir peritoneum penderita infertil dengan endometriosis. Departemen/SMF Obstetri dan 
Ginekologi FK Unair/RSUD dr. Sutomo Surabaya. 2012.

9. Swarnakar S and Paul S. Curcumin arrest endometriosis by downregulation of matrix metalloproteinase-9 activity. Indian J. Biochem. Biophys. 2009;46:59-65.

10. Aggarwal BB, Gupta SC and Sung B. Curcumin : an orally bioavailable blocker of TNF and other pro-inflammatory biomarkers. British Journal of Pharmacology. 2013;169:1672-92.

11. Vigano P, Parazzini F, Somigliana E and Vercellini P. Endometriosis: epidemiology and aetological factors. Best Practice \& Research Clinical Obstetrics and Gynaecology. 2004;18(2):177-200.

12. Mulayim N and Arici A. The relevance of the peritoneal fluid in endometriosis-associated infertility. Human Reproduction. 1999;14(2):67-76.

13. Gupta S, Goldberg JM, Aziz N, Goldberg E, Krajcir $\mathrm{N}$ and Agarwal A. Pathogenic mechanism in endometriosis-associated infertility. Fertility Sterility. 2008;90:247-57.

14. Bedaiwy MA, Falcone T, Sharma RK, Goldberg JM, Attaran M, Nelson DR and Agarwal A. Prediction of endometriosis with serum and peritoneal fluid markers: a prospective controlled trial. Human Reproduction. 2002;17(2):426-31.

15. Gazvani MR, Christmas S, Quenby S, Kirwan J, Johnson PM and Kingsland CR. Peritoneal fluid concentrations of interleukin-8 in women with endometriosis: relationship to stage of disease. Human Reproduction. 1998;13(7):1957-61.

16. Carlberg M, Nejaty J, Froysa B, Guan Y, Soder O and Berqvist A. Elevated expression of tumor necrosis factor- $\alpha$ in cultured granulosa cells from women with endometriosis. Human Reproduction. 2000;15(6):1250-5.

17. Bullimore DW. Endometriosis is sustained by tumour necrosis factor- $\alpha$. Medical Hypotheses. 2002; 60(1):84-8.

18. Kim YS, Ahn Y, Hong MH, Joo SY, Kim KH, Sohn IS, Park HW, Hong YJ, Kim JH, Kim W, Jeong MH, Cho JG, Park JC and Kang JC. Curcumin attenuates Nuclear Factor- $\mathrm{kB}$, c-Jun NTerminal Kinase and p38 in Tumor Necrosis Factor- $\alpha$-Stimulated Endothelial Cells. The Korean Society of Circulation. 2006;36:482-9.

19. Morrison LJ and Marcinkiewicz JL. Tumor necrosis factor- $\alpha$ enhances oocytes/follicle apoptosis in the Neonatal rat ovary. Biology of Reproduction. 2002;66:450-7.
20. Chen $G$ and Goeddel DV. TNF-R1 Signaling: Beautiful Pathway. Science. 2002;296.

21. Friberg A. Granulosa Cell Apoptosis, Transcriptional Regulation by the nuclear progesterone receptor. Department of Physiology/Endocrinology, University of Gothenburg, Sweden. Intellecta Infolog AB. 2009.

22. Kalimuthu S and Se-Kwon K. Cell survival and apoptosis signaling as therapeutic target for cancer: Marine bioactive compounds. International Journal of Molecular Sciences. 2013;14:2334-54.

23. Pekalski J, Zuk PJ, Kochanczk M, Junkin M, Kellog R, Tay S and Lipniacki T. Spontaneous NF$\kappa \mathrm{B}$ activation by autocrine TNF- $\alpha$ signaling: A computational study. Plos One. 2013;8(11):78887.

24. Zolti M, Meirom R, Shemesh M, Wollach D, Mashiach S, Shore L and Rafael Z.B. Granulosa cells as a source and target organ for tumor necrosis factor- $\alpha$. Federation of European Biochemical Societies. 1990;261(2):253-5.

25. Gonzalez-Navarrete F, Eisner V, Morales P, Castro O, Pommer R, Quiroga C, Lavandero S and Devoto L. Tumor necrosis factor- $\alpha$ activates nuclear factor$\kappa \mathrm{B}$ but does not regulate progesterone production in cultured human granulosa luteal cells. Gynecological Endocrinology. 2007;23:377-384.

26. Singh $\mathrm{S}$ and Aggarwal BB. Activation of Transcription Factor NF- $\kappa \mathrm{B}$ is suppressed by curcumin (Diferulolylmethane). The Journal of Biological Chemistry. 1995;270(42):24995-5000.

27. Jobin C, Bradham CA, Russo MP, Juma B, Narula AS, Brenner DA and Sartor RB. Curcumin blocks cytokine-mediated NF- $\mathrm{BB}$ activation and proinflammatory gene expression by inhibiting inhibitory factor I-kB kinase activity. The Journal of Immunology. 1999;163:3474-84.

28. Gupta SS, Prasad S, Kim JH, Patchva S, Webb LJ, Priyadarsini IK, Aggarwal BB. Multitargeting by curcumin as revealed by molecular interaction studies. Natural Product Report. 2011;28:1937-55.

29. Tao Y, Zhang Q, Huang W, Zhu H, Zhang D, Luo W. The Peritoneal Leptin, MCP-1 and TNF- in the Pathogenesis of Endometriosis-Associated Infertility. American Journal of Reproductive Immunology. 2010;65:403-6.

30. Oral E, Olive DL, Arici A. The peritoneal environment in endometriosis. Human Repro-duction Update. 1996;2(5):385-98. 